\title{
Detroit Works Long-Term Planning Project: Engagement Strategies for Blending Community and Technical Expertise
}

Toni L. Griffin ${ }^{1, *}$, Dan Cramer ${ }^{2}$ and Megan Powers ${ }^{2}$

1 J. Max Bond Center on Design for the Just City, Spitzer School of Architecture, The City College of New York, 141 Convent Avenue, New York, NY 10031, USA

2 Grassroots Solutions, 2828 University Avenue SE, Suite \#150, Minneapolis, MN 55414, USA; E-Mails: dan@grassrootssolutions.com (D.C.); megan@grassrootssolutions.com (M.P.)

* Author to whom correspondence should be addressed; E-Mail: tgriffin@ @cny.cuny.edu; Tel.: +1-202-679-7668.

External Editor: Sharon E. Sutton

Received: 12 February 2014; in revised form: 24 September 2014 / Accepted: 25 September 2014 / Published: 16 October 2014

Abstract: In January 2013, civic leaders, community stakeholders, and residents came together to release Detroit Future City: 2012 Detroit Strategic Framework Plan, a guiding blueprint for transforming Detroit from its current state of population loss and excessive vacancy into a model for the reinvention of post-industrial American cities. Three years prior, the U.S. Census had reported that the city had lost $24 \%$ of its population over the last decade and had experienced a $20 \%$ increase in vacant and abandoned property, bringing total vacancy to roughly the size of Manhattan. In addition to physical and economic challenges, Detroiters had also acknowledged significant barriers to effective civic engagement. Foremost among these barriers were a profound sense of immobilization, planning fatigue, and a general perception of cynicism about planning and engagement efforts. These challenges were compounded by historic racial dynamics and tension. This case study elaborates on the comprehensive and innovative civic engagement executed in a citywide planning process called the Detroit Works Project, which took place from late 2010 through late 2012. For the citywide planning process to be successful and sustainable, civic leaders and project funders committed to a planning initiative that would be different from previous efforts, in large part because the "owners" of the process would be diverse and inclusive across all community sectors. The case study, written by three of the key consultants from the project, describes four key civic engagement strategies deployed in the 
creation of the strategic framework: (1) addressing profound challenges of culture, race, and politics by deliberately building trust; (2) elevating community expertise by fostering a sense of ownership of the process; (3) blending technical and community expertise; and (4) viewing civic engagement as an ongoing two-way conversation rather than a series of large-scale episodic events. This article elaborates on important lessons that other communities might learn from Detroit's planning initiative in relation to these strategies. It concludes with a brief summary of the results and implications of the civic engagement process.

Keywords: Detroit; Detroit future city; civic engagement; community expertise; community; participation; stakeholder; civic infrastructure

\section{Introduction}

Increasingly, authentic and inclusive civic engagement has grown to be a core element of many planning processes [1] Though definitions of civic engagement (sometimes called "community engagement") vary, many people understand it as inclusive of both political and non-political processes [2]. Participating in civic life can include activities like voting, attending public meetings, advocacy work, and placemaking efforts, among others. Within the urban planning space, those who spearhead initiatives and planning processes have seen firsthand the tremendous benefits of engaging a wide variety of stakeholders around planning concerns that affect them and their communities. Not only does meaningful civic engagement inform the process and help ensure that planning recommendations and decisions reflect community priorities and experiences, but it can also improve the traction and sustainability of an initiative by building credibility and trust, fostering transparency, and, ultimately, helping to raise visibility and spark demand and support for the plan. Scholars now refer to this type of engagement as "robust civic engagement", where the overarching goals are to build a civic community, where civic infrastructure is supported, and long-term community capacity and leadership is enhanced [3]. In short, civic engagement, whether at the neighborhood or citywide scale, strengthens both the planning process itself as well as its lasting outcomes.

Certainly, designing and executing a successful civic engagement process in ways that are meaningful to both organizers and participants can be challenging. The number and diversity of voices participating, the quality of data and input, the credibility of organizers and presenters, and the presence of political trust and transparency are just some of the factors that can influence whether or not an engagement process is effective and substantive [4].

This article explores civic engagement in the successful multi-year comprehensive planning process of the citywide Detroit Works Project: Long-Term Planning (DWPLTP) initiative. The purpose of the project was to develop a citywide strategic framework that represented a shared vision for Detroit's economic recovery, creating more sustainable land use patterns, revitalizing neighborhoods, reconfiguring infrastructure and city services, utilizing public land assets, and increasing civic capacity. This descriptive case study of the project, written by three of the project's key consultants, offers the perspective of practitioners who were anything by objective observers of DWPLTP but rather were deeply invested in the process. We hope that our critical analysis of the four key civic engagement 
principles that underpinned our work and the tangible evidence of its outcomes substantiates the fairness of our interpretation.

The case study characterizes the four civic engagement principles as they evolved and shaped the resulting strategic framework, which we believe could be instructive for other communities. The four principles are:

1. Recognize the profound challenges that culture, race, and politics can present to a civic engagement process. Address these challenges through a deliberate strategy of building trust and enthusiasm with and within the community;

2. Elevate community expertise by fostering a sense of ownership of the process among local civic leaders, as well as adopting an expansive view of community that includes the perspectives not only of residents, but also of multiple sectors and segments of the community;

3. Create an intentional approach for blending technical and community expertise on a citywide scale. Acknowledge experiential and anecdotal inputs as valid, and integrate them with technical research and analysis to create a more accurate and inclusive case for change and implementation;

4. View civic engagement as an ongoing two-way conversation rather than a series of large-scale episodic events. Provide a wide range of opportunities and methods for people to interact with, learn about, provide feedback to, and in other ways shape the resulting plan.

\section{Project Overview}

\subsection{Origins of the Strategic Planning Process and Key Players}

The Detroit Works Project was initiated by newly elected Detroit Mayor Dave Bing in mid-2010. It stemmed from a desire by the mayor, civic leaders, and the Kresge Foundation (the principal funder of the project) to better address the city's growing challenges of vacancy, abandoned buildings, and population loss. The Foundation enlisted urban planner Toni L. Griffin, who had extensive experience working for other large cities on urban redevelopment and urban design, to lead the technical work for the initiative. Griffin assembled a world-class technical and civic engagement team that included the Detroit firm Hamilton Anderson Associates, along with a number of other consultants and technical experts (see the Appendix for the complete list of Planning Team members).

The duration of the entire Detroit Works Project was from mid-2010 to the completion of the strategic framework in January 2013. After the first phase of the project in late 2010, and upon completion of initial existing conditions audits and early rounds of civic engagement, project leaders recalibrated the process, bringing on additional technical expertise to address specific challenges like infrastructure and local expertise to lead a more robust civic engagement component. In mid-2011, a dedicated civic engagement team was assembled to complement the technical team, led by the Detroit Collaborative Design Center at the University of Detroit-Mercy. The local nonprofit organization Michigan Community Resources and the engagement consulting firm Grassroots Solutions joined the civic engagement team as well. In addition, a volunteer group of more than a dozen local community and organizational leaders, called the Process Leaders, was enlisted to help guide and advise civic engagement for the project as activities began to ramp up. Finally, a team of communications consultants led by Lovio George and Canning Communications helped to craft and disseminate regular 
project communications and a media strategy. The entire DWPLTP was managed by a multi-sector Steering Committee with representatives of city government, philanthropy, nonprofits, business, and other local institutions.

\subsection{Engagement Tactics for the Strategic Planning Process}

The civic engagement team, with support from the Process Leaders, worked with the technical team to design a set of engagement methods not only to gather community input to inform the strategic framework, but also to build trust and enthusiasm in the process, as well as provide opportunities for community stakeholders to learn about and discuss urban planning issues that were relevant to their lived experiences. To this end, an innovative mix of in-person and virtual civic engagement tactics were layered and deployed throughout the process, with an average of three to four engagement opportunities per week. Some of these tactics were designed to accomplish one objective - such as gathering community input — while other tactics helped advance all the objectives (gathering input, trust-building, and community learning/dialogue). Following is a list of tactics and their primary purpose.

\subsubsection{In-Person Engagement Tactics}

1. Large-scale town hall meetings (community learning);

2. Topic-based summits (gathering input, community learning/dialogue, and idea generation);

3. Community conversations (gathering input, building trust, and community learning/dialogue);

4. The "Roaming Table" (building trust);

5. Open houses and drop-in visits to the project's Home Base office (gathering input, building trust, and community learning/dialogue);

6. Attending or presenting at existing community meetings (gathering input and community learning/dialogue);

7. Street team door-knocking and leafleting (building trust);

8. Technical team working sessions (synthesizing input).

2.2.2. Virtual Engagement Tactics (Including both Online and Phone)

1. Telephone town halls (building trust and community learning);

2. "Detroit $24 / 7$ " online planning game (gathering input, idea generation, and community learning/dialogue);

3. E-newsletters (building trust and community learning);

4. Home Base "hotline" calls (community learning);

5. Website updates and social media (building trust and community learning);

6. "Detroit Stories" video history project (building trust and community learning/dialogue);

7. Earned media, such as print, radio, and television media and communications features (building trust and community learning).

Evaluation staff members of the civic engagement team carefully documented and created a quantitative analysis of the engagement inputs collected, capturing common themes within the key challenges, opportunities, and ideas expressed. This analysis was shared with the technical team during 
the development of the strategic framework. More information that describes the engagement methodology, participation and demographics, as well as content and themes of community input can be found in an extensive 300-page DWPLTP Civic Engagement Appendix [5]. In addition, several of the key engagement tactics that helped to shape civic engagement as an ongoing two-way conversation are described at greater length in Section 3.2.4 (Strategy \#4) of this article.

\subsection{References for This Case Study Analysis}

This descriptive case study offers four key strategies used in Detroit that may prove instructive to other cities in making urban planning processes inclusive and viable, especially in a complex economic and sociopolitical environment. The four key strategies were shaped by a comprehensive audit [6] of civic engagement conducted by Grassroots Solutions in the city of Detroit previous to the Detroit Works Project. Completed in 2010, the audit surfaced themes and insights about Detroit's context, past planning efforts, engagement assets, challenges, and opportunities. Several of these insights are shared in Section 3.2.1 (Strategy \#1) of this article.

\section{Results and Discussion}

\subsection{Setting the Stage}

In March 2010, after months of an interim mayor and a special election, newly elected Detroit Mayor Dave Bing delivered his first State of the City address to a hopeful citizenry eager to stand behind local leaders who represented a new era of integrity and access. Mayor Bing was well aware of the profound fiscal, operational, economic, and social justice challenges he inherited, and he had already begun conversations with civic and philanthropic leaders about organizing a process to address these concerns comprehensively. In his first public address to the city he noted that "we have an opportunity to reinvent Detroit like never before.... Any plan will involve direct participation from our community because that's where our real strength is -in the commitment and connection Detroiters share with our city and each other. Every Detroiter has a voice and a role in this process [7]."

This statement lifted the community and raised expectations that the new administration would be transparent, inclusive, and willing to work with communities towards positive change. But Detroiters were not new to civic participation, and they had certainly been let down by hollow public commitments of inclusion numerous times before. A healthy amount of skepticism was present.

The city's leadership had been plagued by corruption for many decades, and city government had not been viewed as a reliable partner in recent years. The Detroit civic community of business, nonprofits, philanthropy, and community development sectors had retreated into their own silos to effect change on the ground [8]. As a result, there were many "messengers of change" in Detroit, each with different levels of credibility and currency within the larger community. In addition, the local economy was in grave trouble. The city had experienced a $24 \%$ loss in population over the previous decade, as well as a $20 \%$ increase in vacant and abandoned property-equivalent to 20 square miles (roughly the size of Manhattan) [9]. Finally, the city's rate of physical deterioration and struggle to provide resources and deliver basic services had intensified in recent years. It is within this context that DWPLTP began. 


\subsection{Process and Strategies}

Echoing the mayor's pronouncement that every Detroiter would have a voice and role in the citywide planning process, the project funders - the Kresge Foundation and the Ford Foundation - also expressed a strong interest in designing inclusive and meaningful civic engagement. After months of collaboration to develop a scope of work, create a project schedule, and assemble technical and civic engagement teams, city officials, community leaders, consultants, and foundation leaders launched the project in September 2010. It kicked off with five town hall-style meetings to introduce the planning process and articulate how it would fulfill Mayor Bing's State of the City address commitment of including the voices of Detroiters. The purpose of the collaborative project was to develop a strategic framework-essentially a blueprint for decision-making that could be used by multiple sectors-reflecting the best of Detroit's imagination and innovation to create a more prosperous, connected, sustainable, and socially-just city.

Residents' response was tremendous in this early phase of the project; Detroiters were eager for the opportunity to engage with the new city leadership. Nearly 5000 people participated in the first five town hall meetings alone, which proved to be logistically challenging and inhibited the kind of interactive dialogue and community learning that could take place. It was immediately apparent that the community was not yet ready to turn its attention towards visioning Detroit's future in the face of urgent day-to-day challenges and inefficiencies. Many attendees wanted to talk more or first about pressing problems in their neighborhoods such as vacant property, crime, and unreliable trash collection. In addition to frayed relationships with city officials, there were concerns and fears about "outsiders" leading the meetings and planning process - individuals with whom trust had not yet been established. Meeting participants wanted instead to interact and have dialogue with local Detroiters and people they knew.

Given the high levels of frustration, especially among residents, about how immediate concerns were being addressed in the city, project leaders recognized the need to make an important shift. The mayor and project funders split the project into two tracks - one to concentrate on immediate needs and interventions called "Detroit Works Short-Term Actions", to be led by the mayor's senior staff, and another to focus on creating a shared and comprehensive vision for long-term transformation called "Detroit Works Project: Long-Term Planning" (DWPLTP) [10].

From the outset of the DWPLTP process, project leaders sought to recalibrate and increase engagement opportunities to optimize the degree of community knowledge, learning, and interactive dialogue. In other words, the project aimed to build stakeholders' awareness and learning about planning issues and solicit their personal views of such issues [11]. In essence, project leaders sought to achieve greater authenticity, scale, credibility, and value through civic engagement efforts. The following elaborates on the civic engagement strategies that evolved as we applied, and adapted, the four key civic engagement principles in the field.

\subsubsection{Strategy \#1: Overcoming the Challenges of Culture, Race, and Politics}

The engagement audit from early 2010 had highlighted and confirmed many of the engagement assets that existed in Detroit, such as the resiliency of residents, a vibrant faith community, a legacy of 
organizing, and robust neighbor-to-neighbor efforts and networks. In particular, audit interviewees considered the people of Detroit to be the city's greatest asset, describing them as resilient, tenacious, loyal, and deeply attached and invested in the future of the place they call home [12]. In addition to the audit, around this time there was an increase in philanthropic investments in Detroit, and energetic and innovative entrepreneurial approaches were beginning to have positive impacts in several neighborhoods. Perhaps most notably, a common sense of readiness for transformational change was emerging among people working and living in the city.

However, the audit also surfaced many historic dynamics and dysfunctions around effective civic participation that remained a stark reality in Detroit, including three important challenges of note. First, and not least among these barriers to effective engagement, was a generally weakened civic infrastructure. The local nonprofit sector was reportedly under-resourced for engagement efforts and projects, which affected the ability of organizations to achieve both scale of reach and depth of outcomes. Much of the existing local organizing or engagement capacity seemed to be constrained by narrow program parameters, shoestring budgets, and limited staff. As one person noted, "In order to get individual voices you have to go door-to-door, but this takes increased resources, and who has the capacity [13]?" In addition, established power centers within various local sectors sometimes impeded new approaches, ideas, and voices. Organizations and sectors in Detroit were often described as "siloed" - with tense or frayed relationships common among sectors-as well as highly turf conscious [14]. Due to many of these capacity and infrastructure challenges, taking engagement efforts to a multi-neighborhood or citywide scale had been historically an intimidating endeavor.

A second challenge was the common feeling in Detroit of being "planned to death." The severity of the economic crisis and the physical devastation within the city was palpable. As one participant said, "I tend to be little more than skeptical until I see some (any) evidence of change, first. Planning sessions do not make me hopeful". There was a sense of collective cynicism about systemic change, even as people expressed urgency and impatience for tangible progress. However, long-term solutions are both complex and daunting, and, therefore, it was not always easy to gain traction on implementation, leaving residents to feel like nothing was happening [15]. These kinds of factors combined to fuel a culture of profound immobilization among Detroiters [16]. As one leader noted early in the process, "It's easy to get bogged down in big problems".

Lastly, the challenges of racial disparity and racial tension were a constant undercurrent in the city. Despite a majority population of 82\% African Americans in Detroit in 2010 [17], there was a strong sense among residents that there had not been an adequate presence of African-American voices in positions of leadership and power within city institutions, corporate businesses, and the philanthropic sector. Similarly, many people articulated the need for more proportional access and representation by African Americans and other communities of color as active participants in decision-making about Detroit's future. Broadly speaking, achieving racial equity had not been a leading driver for planning decisions in the city. As one person noted, "There is deep and historical racial distrust. The divisions that we have here are significant. The economic disparities around race are so huge it makes it hard to get past it [18]". Compounding this tension was a common fear of "outsiders [19]", stereotypically defined as nonresident, influential, wealthy, professional, and white, running the process as well as outsiders "taking over the city". When considered in the context of place attachment, the bond between people and place, race, class and gender identity have a large influence on how the "insiders"- typically 
the marginalized people of a community - feel a lack of empowerment or position in affecting future decisions about their community [20]. The insider-outsider dynamic was racially based (black versus white populations, which sometimes translated to class differences); geographically-based (city versus suburbs versus out-of-town); and tenure-based (recent versus long-standing residents).

To be sure, issues of race, culture, and politics often complicate and strain attempts to develop and implement citywide planning processes. However, what was unique about the case of Detroit's planning process was that the civic engagement team acknowledged these challenges, considered public sentiment after the tense first set of large-scale meetings, and was determined to craft a deliberate strategy to overcome such infrastructural, racial, and political barriers by intentionally and intensively focusing on building and rebuilding trust. This helped the project achieve the objectives of scale and credibility. Civic engagement team leaders realized that building trust explicitly within and across all segments of the Detroit community could improve significantly the community stakeholders' impressions of, participation in, and ultimate buy-in of the effort. Building trust meant focusing on inviting people into the planning conversation both earlier and more inclusively than had been done in the past, and it required investing time and resources in outreach and cultivating relationships. This trust building felt at times like a case of one step forward and two steps back. One participant in the project in mid-2012 put it this way: "I came into this with the utmost respect for DWP, and I still have that, but there is an apparent disconnect with the community that I can sense".

Project leaders attended existing community meetings across the city to listen to people's questions and perspectives on their own turf and in their own terms. They made a concerted effort to reach out to people and groups that may have been overlooked in prior planning processes. Project staff members were also trained in responsive listening skills and on how to conduct productive one-on-one meetings. In addition, transparency and accountability were crucial to building trust. Thus, project leaders developed an ongoing feedback loop - meaning both delivering frequent and timely updates and notifying stakeholders of upcoming engagement opportunities, as well as soliciting community input in targeted ways. Communications methods (also known as information out) included a regular e-newsletter, project website [21] and social media posts, periodic canvassing and distribution of materials, and coverage in print, radio, and television outlets. Community input and perspectives (also known as information in) were sought through dialogue at meetings, events, one-on-one conversations, and story gathering, among other methods. These concurrent and complementary feedback mechanisms encouraged greater levels of engagement, trust, constituency building, and support from community stakeholders; contributed to the credibility of the process; and ameliorated the aforementioned challenges of planning fatigue, weak civic infrastructure, and negative racial and cultural dynamics.

Certainly, cultivating trust and enthusiasm through relationship-building and real-time feedback loops took time and resources. In fact, some of the project's Steering Committee members were hesitant at first to make the significant investment of time and resources in engagement activities that would not inform the content of the strategic framework plan directly. However, in the end, building trust proved a worthwhile investment. More than $60 \%$ of DWPLTP survey respondents indicated that they felt "more hopeful" after participation in the initiative [22]. In the words of one participant, "I see how feedback has been used, I see that the team is thinking about implementation". Not only did the 
trust-building strategy improve the transparency and authenticity of the process, it also better positioned the Framework Plan for sustained demand and buy-in when the time came for implementation.

\subsubsection{Strategy \#2: Designing a Process that Elevates Community Expertise}

The civic culture of Detroit has worked frequently in an "us versus them" environment [23]. For example, local community groups have often organized for dialogue and change out of necessity because of the absence and/or distrust of institutional leadership, including government, philanthropy, and business. "Community" in this case refers to the "grassroots", defined as Detroit residents and those organized to work on behalf of local Detroiters. The anger expressed by the audience at the first public meetings in September 2010 had built from a desire to have Mayor Bing address them directly, particularly after having emphasized the importance of community engagement in his first State of the City address just a few months earlier. There was also a common feeling that once again, the usual public officials ("grass tops") and "outsider" consultants already had a plan. Evidence of how the grassroots would be meaningfully a part of the process was not presented or represented clearly in the initial engagements.

Often in planning processes, the tension between adopting a "community-driven" approach versus the perceptions of a "stakeholder-led" approach surfaces early, and usually a choice is made to adopt one or the other. It became clear that DWPLTP's goals of robust and authentic engagement required not settling for a "grassroots" versus a "grass tops" approach to engagement, but rather creating a new paradigm of engagement that expanded the definition of community to include multiple sectors in dialogue together to share expertise and inform the final planning outcome. In other words, project leaders opted to avoid the dichotomy of either a "top-down" or "bottom-up" approach. Instead, they explored how to involve community members deeply in participating in the process and influencing its outcomes without misleading the public into thinking that all decisions would stem from the ground up. In this way, civic engagement for the project was reconceived to be citizen-shaped, not citizen-driven. This was an important distinction that helped clarify expectations and roles, although it proved a challenge at times not to revert back to one end of the spectrum or the other.

While the initial five town hall meetings were difficult to manage logistically, and, in some cases, became a forum for residents' anger and frustration, the meetings surfaced ultimately an enormous amount of data about what Detroiters witnessed firsthand about the condition of their neighborhoods. In the early meetings, many people spoke in great detail about their communities, often citing problem addresses, blocks and intersections, as well as about the resources and local activism already working to remedy the problems. Pivoting from the early large-scale meetings, which represented primarily residents as just one segment of Detroit's larger community, project leaders sought to adopt a more expansive and inclusive view of community. This more expansive definition of community included large and small business owners, the financial and philanthropic sectors, health and educational leaders, and academics. This local knowledge about current conditions and expertise about urban issues were highly valued by project leaders. Since many local leaders wore multiple hats as different segments of community crossed over, DWPLTP sought to weave these segments together at meetings, events, and activities where possible, rather than approaching them in isolation from one another. Indeed, early 
project planning by the Detroit Collaborative Design Center often featured a graphic image of the interconnected segments of community (depicted in Figure 1).

Figure 1. Segments of community. (Image credit: Detroit Collaborative Design Center).

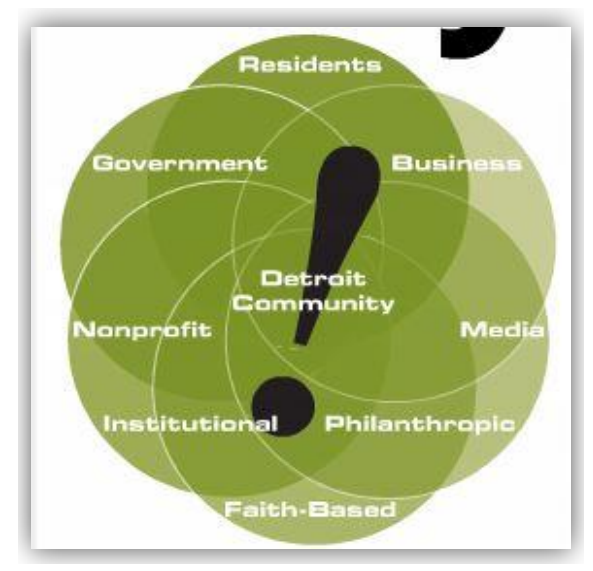

Local expertise was elevated by both a more expansive definition of community and by the careful consideration of who would be at the table to shape and execute the engagement. Another key engagement strategy that the DWPLTP developed and executed was the intentional strengthening of local capacity for ongoing and future engagement efforts. An essential part of this, and one that grew directly out of the early investment in trust building and relationship building, was the creation of a new group called the Process Leaders.

The more than a dozen local community leaders who comprised this group were selected for their expertise in civic engagement and local community knowledge among different racial, cultural, and age groups, as well as geographic areas of the city. The Process Leaders were charged with meeting weekly to advise and guide the engagement team and to help design and execute particular engagement activities and events. This role went beyond the typical "community advisory group" to active participation in decisions about where, when, and how engagement would roll out. This ameliorated the widespread perception of "us versus them" that had plagued previous projects. The Process Leaders helped to signal to Detroiters that engagement would go beyond the "usual suspects", and this generated broad excitement.

\section{Examples of Community "Fingerprints" in DWPLTP}

One of the richest areas of community input dealt with the Neighborhoods planning element-mentioned most frequently out of more than 180 DWPLTP planning topics. Participant comments and reflections about the most critical quality of life indicators shaped this aspect of the strategic framework. Such comments and ideas included:

Reduce blight by making properties cleaner and safer;

$\checkmark$ Encourage people to stay in Detroit, contribute to community, be neighborly, and maintain property;

$\checkmark$ Get together with a group of neighbors and fellow citizens as a way of improving the neighborhood;

$\checkmark$ Encourage community-based and youth-focused programs to improve safety in moderate vacancy areas. 
The Process Leaders group was an innovative way to respond to the sense of weakened civic infrastructure and the sense of us versus them or insiders versus outsiders that often permeated previous planning projects in Detroit. It was a method used not only to cultivate broad participation and collaborative ownership, but also to build the local capacity for ongoing and future engagement efforts. Process Leaders strengthened relationships with each other, and in some cases, sought opportunities to work together even beyond DWPLTP. Engagement capacity was also built by training project ambassadors and street team canvassers, connecting people across silos and sectors where possible, and exposing the local civic leaders to new engagement tools and methods. The Process Leaders group also benefitted the engagement process by helping to build trust and getting resources to flow back into the city. In sum, the principle of developing and supporting local leadership helped address the capacity and infrastructure challenges and take the effort to scale. As one Process Leader reflected, "I think over the next three to five years, you're going to see radical change in Detroit. It's already underway [24]".

\subsubsection{Strategy \#3: Creating an Intentional Approach for Blending Technical and Community Expertise at a Citywide Scale}

The first two strategies described how the engagement process was improved through methods that helped build trust and develop local capacity. In addition to these process design elements, an optimal outcome - the actual content of the Framework Plan - was also extremely important to all involved. Given the community's concerns about a "top-down" planning approach, where city leaders and their planners were perceived to already have the solution to an already framed set of problems, there was early push back that the process should be "community-driven". A community-driven process was understood as a process where the knowledge of local residents, both subjective and spatial, reflects their common experience and knowledge of everyday life, therefore better equipping them as the "experts" at identifying technical solutions that meet their realities and needs [25]. It was clear that this either/or proposition would not yield the best solution for addressing Detroit's severe economic, social, and spatial challenges that operated at both the citywide and neighborhood scale. Instead, an interdisciplinary approach was needed, integrating the best practices of planning and design, social science, and community-based problem solving. Values around immediate needs combined with innovative spatial solutions allowed both the practical and the aspirational. The technical solutions reflected the complexity of city dwellers' everyday lives.

Therefore, one of the unique features of the DWPLTP process was the aspiration to truly blend technical expertise with community expertise. Community expertise was defined as the inputs collected by community participants that included experiential knowledge and observations about current conditions and activities on the ground. That is, Detroiters were seen as the data "recorders" or experts of their own communities. Including their observations and ideas in the work would ensure that they could see their "fingerprints" on the resulting strategic framework. Technical and planning experts accepted the premise that these types of experiential and anecdotal inputs are valid.

Towards this end, project leaders designed ways to gather and record significant and wide-ranging input and perspectives, incorporate them into the technical analysis in real time, and demonstrate to the community how their inputs were incorporated. This process was referred to as a "civic engagement 
feedback loop" (see diagram in Figure 2). In terms of the precise methodology for gathering and analyzing community input, extensive methods were built into the process and were used in a variety of face-to-face and virtual engagement efforts (see Figure 3 for types and locations of face-to-face engagements). These included participant comment forms (largely handwritten responses which were then transcribed), electronic and phone surveys and snap polls, Facebook surveys, comment forms on the project website, Keypoint ${ }^{\circledR / “ c l i c k e r ” ~ p o l l s, ~ i n t e r a c t i v e ~ m a p p i n g ~ e x e r c i s e s, ~ g e o g r a p h i c a l l y-l i n k e d ~}$ responses through the Detroit 24/7 online game, dot voting exercises, extensive meeting notes, live court reporter scribes and transcriptions, video interviews, small group participant note taking, one-on-one interview notes, and evaluation forms. Both open-ended and close-ended questions were asked. All of these data inputs were analyzed using Microsoft Access and Microsoft Excel.

Figure 2. The civic engagement feedback loop. (Image credit: Detroit Future City: 2012 Detroit Strategic Framework Plan).

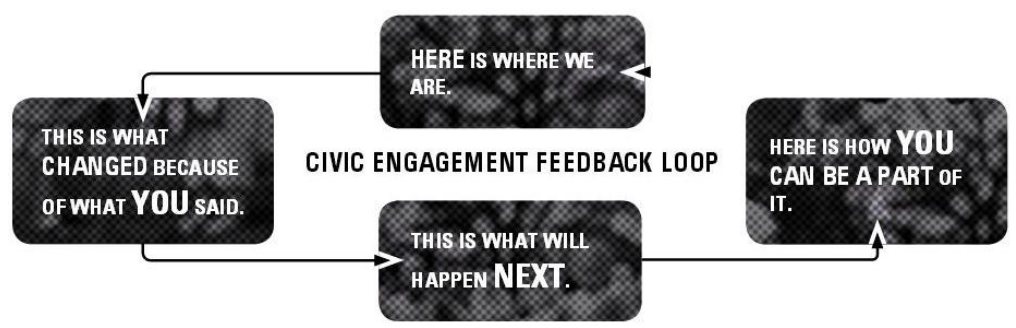

Figure 3. Map of all face-to-face civic engagement activities executed by the Detroit Works Project throughout the city. (Image credit: Detroit Future City: Civic Engagement Appendix).

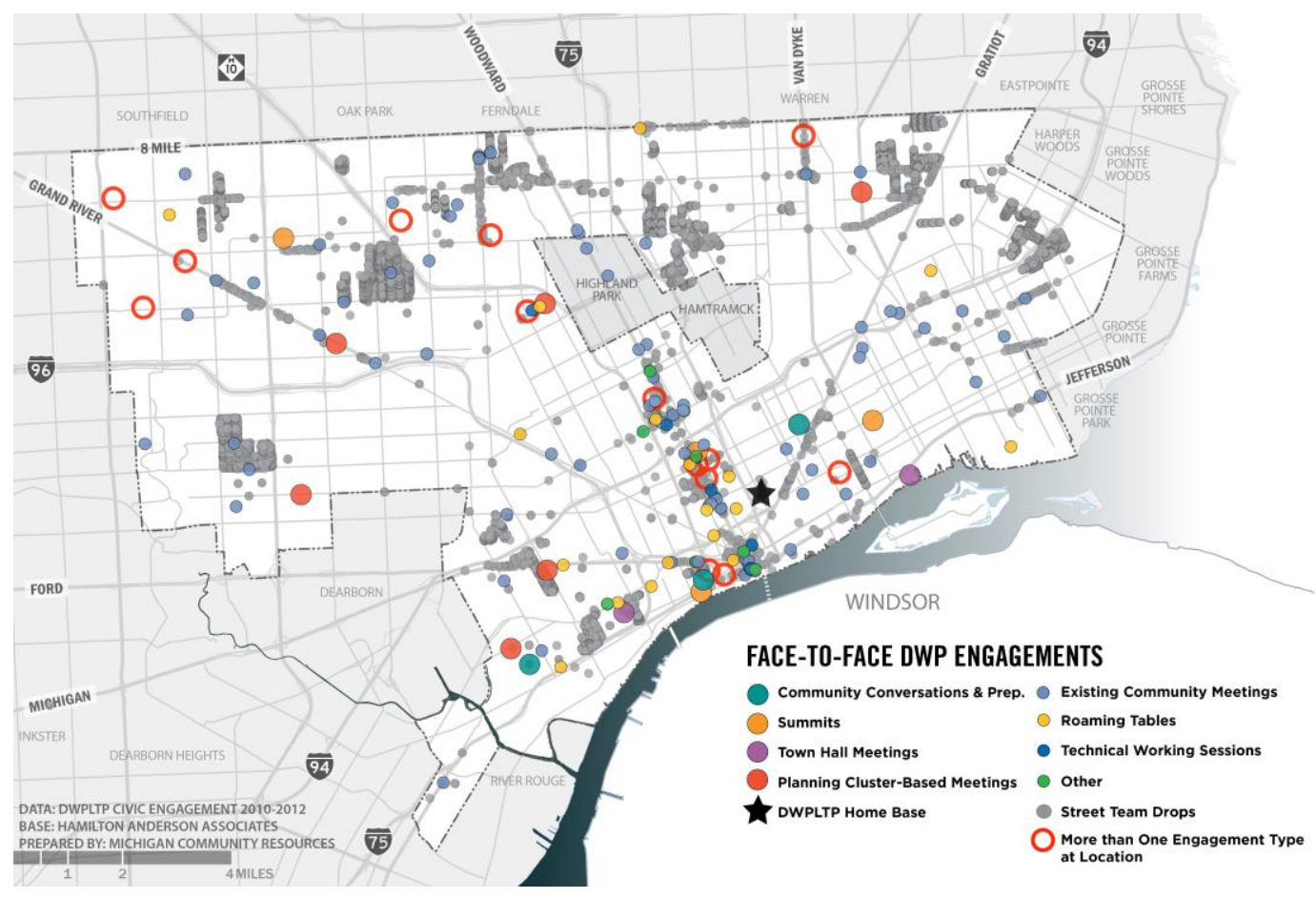


Project leaders strove to make engagement authentic, meaningful, and ongoing in the creation of a strategic framework that would be reflective of community perspectives and priorities, combined with technical data research and analysis. The goal of blending technical and community expertise was seen not only to benefit the final plan itself, but also to prime all community sectors to sustain its demand and implementation after the planning process was completed.

However, this ambitious aspiration of blending community and technical expertise came with pitfalls as well. For one, it was messy. The observations and priorities articulated by residents did not always translate laterally to the levels and types of analysis on the technical side. For example, parents shared specific input about the quality and characteristics of particular Detroit public schools, with comments such as: "Safety at a school is the number one thing that determines whether or not a parent will send their child to that school-is my child safe and do you care about my child [26]?" While valid and deeply important to residents' quality of life in neighborhoods, such input sometimes did not translate easily to technical assessments and recommendations at the systems level.

In addition, the integration of community expertise proved logistically and intellectually challenging at times. It proved enormously difficult to incorporate feedback from community sectors in real time (and to circulate out what was heard, what changed, and why) in the midst of also developing and advancing the rigorous, multifaceted technical work. Several reasons explain this difficulty. For one, resource and timing constraints - and sometimes unjustified deadlines - competed constantly with the need for depth and assessment of the community inputs. Certainly, this inhibited the ability to incorporate community input, but project leaders and advisors strove for the ideal of blending as much as possible. A second reason for the difficulty in blending inputs in real time was imbedded in the very nature of the "wicked problem [27]" of the planning scope. The large amount of content coming from both technical and community data created a constant cycle of discovering the nature of the problems while at the same time also investigating their dimensions and solutions in order to make timely decisions to move the process forward. And finally, even with a robust community engagement process, the thousands of people who participated and provided significant input still represented only $15 \%$ to $16 \%$ of Detroit's total population. Still fewer of this number were signed up to receive ongoing project communications and updates via email, so the project was unable to stay connected over time with most participants.

Perhaps the greatest degree of successful technical and community blending came within the three months following the initial meetings in 2010 through smaller organized follow-up conversations designed to gather more community intelligence about the challenges and opportunities for Detroit's neighborhoods. These smaller meetings engaged not only residents, but also attracted other segments of the community to surface insights and data. For instance, many participants (32.8\%) felt that access to high quality education was "the most critical" to their quality of life [28]. A careful recording of these inputs represented the initial set of "community expertise data" incorporated into the early phase of analysis. These dialogues ran parallel to an intensive technical assessment of several land use, economic, and social indicators of Detroit's current conditions. When the technical policy audits were blended with the community data, the technical team was able to develop a more accurate and inclusive "case for change" - a comprehensive set of data, both quantitative and qualitative, about issues most critical for the city to address in order to transition towards a more sustainable future. 
The results of these integrated discussions between the community and the technical team produced twelve Imperative Actions - the important core values, goals, and quality of life/quality of business elements necessary to move Detroit into a more sustainable and affordable future. The Imperatives were set during the initial six months of the project and established the direction for subsequent phases and the final recommendations of the Framework.

\section{Imperative Actions}

1. We must re-energize Detroit's economy to increase job opportunities within the city for Detroiters and strengthen the tax base;

2. We must support our current residents and attract new residents;

3. We must use innovative approaches to transform our vacant land in ways that increase its value and productivity and promote long-term sustainability;

4. We must use our open space to improve the health of all Detroit's residents;

5. We must promote a range of sustainable residential densities;

6. We must focus on sizing the networks for a smaller population, making them more efficient, more affordable, and better performing;

7. We must realign city systems in ways that promote areas of economic potential, encourage thriving communities, and improve environmental and human health conditions;

8. We must be strategic and coordinated in our use of land;

9. We must promote stewardship for all areas of the city by implementing short- and long-term strategies;

10. We must provide residents with meaningful ways to make change in their communities and the city at large;

11. We must pursue a collaborative regional agenda that recognizes Detroit's strengths and our region's shared destiny;

12. We must dedicate ourselves to implementing this framework for our future.

Moving into the strategy development phase, blending community and technical expertise became more difficult for the DWPLTP team mainly because: (1) the technical work was at least two to three months ahead of the engagement due to gaps in the civic engagement process to redesign more effective approaches; and (2) the accelerated project schedule with deadlines driven by the political calendar-local elections, legislative conferences, et cetera - constrained greatly the amount of time that the team had for multiple rounds of data synthesis, confirmation, and integration with community sectors. And certainly, the skepticism and planning fatigue mentioned earlier still arose throughout the process, as participants voiced concern about the timeframe for implementation. "You all have collected great ideas for improving the city, but I fear it will go into a report and no action will be taken. I would like to see how these things can become a reality and soon [29]", cautioned one participant.

In hindsight, working groups, inclusive of all community sectors, working across the various planning elements of land use, economic growth, neighborhoods, city systems, public assets, and civic engagement should have been put in place earlier in the process to ensure deeper integration of the blended expertise. That said, the attempt to blend community and technical expertise was successful in the following ways. First, there were many instances where strategies developed by the technical team 
and community expertise were compatible and well aligned. For example, one common idea that surfaced repeatedly in the civic engagement process was to "target different industries and businesses (for growth and development) in different areas of the city". This idea took shape on the technical side as well, as the technical team examined how best to connect the strategies of economic development and land use. Second, the technical team included several Detroit residents who were able to add to as well as validate community expertise coming from the engagement process. Community perspectives about blue-green infrastructure, public safety, and environmental health, in particular, surfaced many times - as one person put it, "We need to transform the city of Detroit into a cleaner, healthier, safer environment [30]." Third, a constant dialogue between the technical team, civic engagement team, and process leaders through weekly coordination meetings helped ensure the most critical and commonly expressed issues and ideas from the community sectors were directed back to the technical team.

\subsubsection{Strategy \#4: Viewing Civic Engagement as an Ongoing Two-Way Conversation Rather Than a} Series of Large-Scale Episodic Events

Oftentimes, civic engagement equates to large-scale events open to the public at large. Routinely a passive experience for attendees, the series of events tend to culminate in a tally of the total number of attendees as proof that the community was, in fact, engaged [31]. Through the DWPLTP process, particularly after its first set of town hall meetings, we learned that the approach needed to be more interactive and responsive to the readiness of the civic community to discuss and participate in designing change for the future.

Authentic civic engagement for this effort demanded that a relationship be built across all community sectors and neighborhoods around the city, not only to complete the planning process successfully, but also to strengthen the capacity to implement the strategies for change (see Figure 4 for the distribution of participant engagement by city zip codes). The process had to involve local participants actively and more visibly in leadership positions. Also paramount was creating a constant demonstration of transparency to maintain engagement, enthusiasm, and trust. In part, this meant placing a high value on the inputs of the community sectors equal to that of the technical data and expertise brought in to provide the best practices from around the world. Small and big creative ideas were shared throughout the civic engagement process, from raising people's awareness of the "LightsOn! Detroit online tracking system allowing residents to communicate where street lights need to be fixed [32]" to discussions of "how we retrofit our built environment, [which] has implications for future costs and usage. You may be paying a higher rate, but with energy efficiency, you are using less [33]”.

While project leaders recognized that face-to-face community meetings and events would provide ways for people to connect, learn, and engage, DWPLTP also layered on a host of virtual and in-person engagement methods for engaging a wider and more diverse range of community participants to learn about, interact with, and provide feedback to shape the strategic framework. These innovative, fun, and interactive tactics were meant to engender an open and ongoing two-way dialogue among all community participants. 
Figure 4. Map of registered participants by zip code. (Image credit: Detroit Future City: Civic Engagement Appendix).

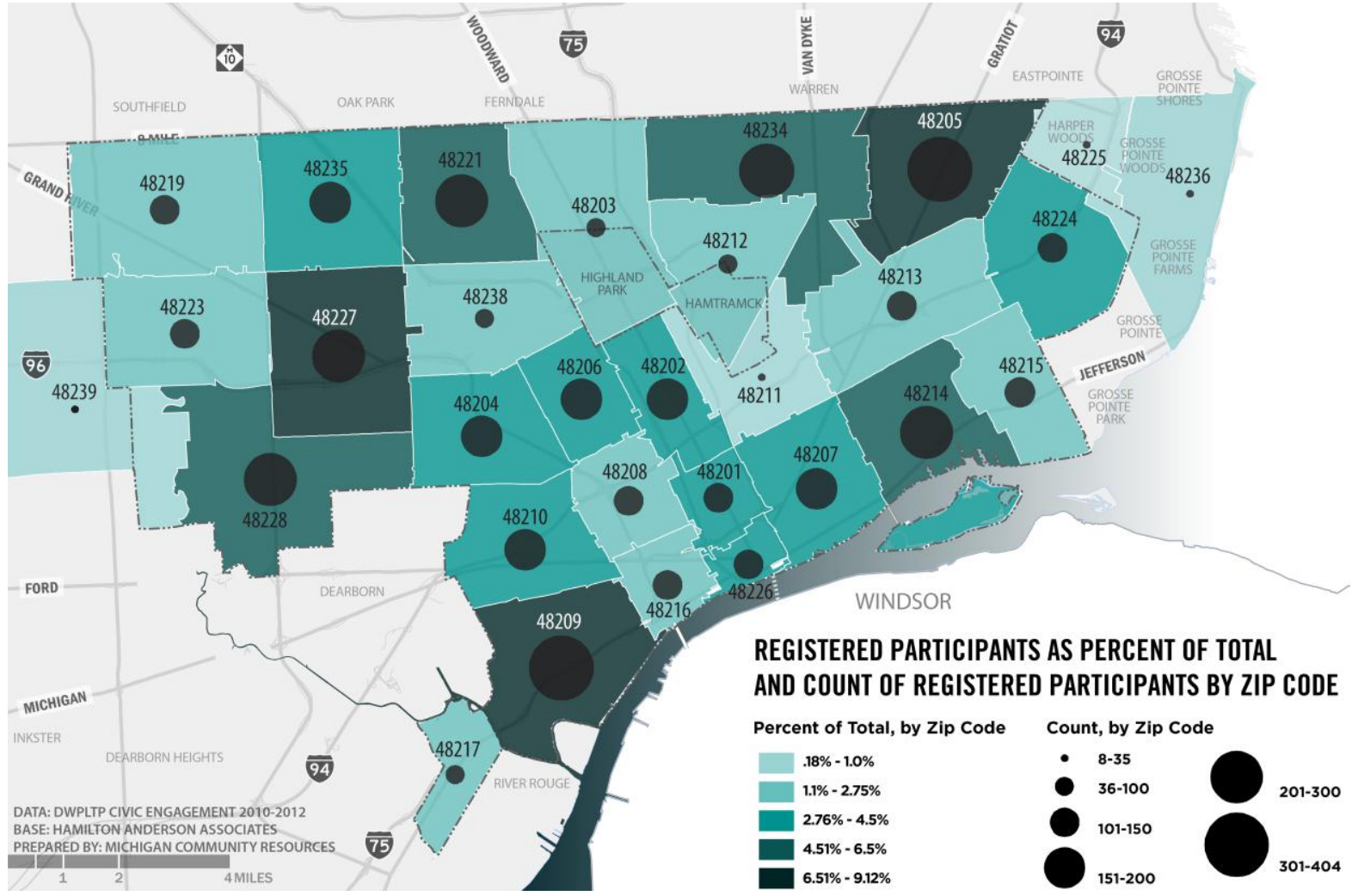

In addition to the more typical meeting-style formats of focus groups, charettes, and town hall forums, the following four innovative tactics are worth highlighting here:

- One of the tactics that helped to facilitate two-way conversation and learning was the "Roaming Table", a small travelling conversation booth that was staffed and stationed at various community locations. Tabling at events and meetings is a common engagement tactic for many efforts. However, the Roaming Table was unique because it could be set up anywhere rather than reaching only event attendees. And rather than being staffed by a project volunteer sitting passively behind a table full of flyers and materials it was designed to be approachable and interactive. The booth was designed inexpensively and could be collapsed to fit into the trunk of a car, so that organizers could transport it easily from place to place. The Roaming Table was ideal for engaging people in brief, one-on-one interactions about DWPLTP as they walked by, both to expose new people to the project as well as to solicit input on a specific planning question. This tactic facilitated more than 600 one-on-one conversations about the project (See Figure 5);

- The project also hosted a series of hour-long telephone town hall events, which reached more than 6000 people and engaged approximately 1300 participants. These were distinct from the five town hall meetings held at the beginning of the project, which were face-to-face facilitated exchanges between technical experts and a larger than expected crowd of participants. A telephone town hall, by contrast, is a virtual meeting that takes place via phone and can be joined from any telephone, such as from the convenience of a person's home. It is a cost-effective 
and accessible technique for those for whom face-to-face meetings are challenging or unappealing. The technology uses an auto-dialer to call a specified list of phone numbers, offering a way to reach a large group of people instantly. People can listen to a speaker or a panel, ask questions in real time, or record messages expressing their perspectives on an issue. The telephone town halls promoted the two-way conversation between the speakers and the callers. These virtual town hall meetings allowed callers to hear project updates from Detroit community leaders, and to join the conversation live by posing their questions and comments. This tactic was particularly effective in engaging those who did not have the interest or ability to attend an in-person meeting, such as those with limited accessibility or who worked at times when community meetings took place. Many seniors participated in the telephone town halls.

Figure 5. The project's collapsible "roaming table" allowed the outreach team to engage over 6000 residents at transit stops, grocery stores, and community events throughout Detroit. (Photo credit: Detroit Collaborative Design Center).

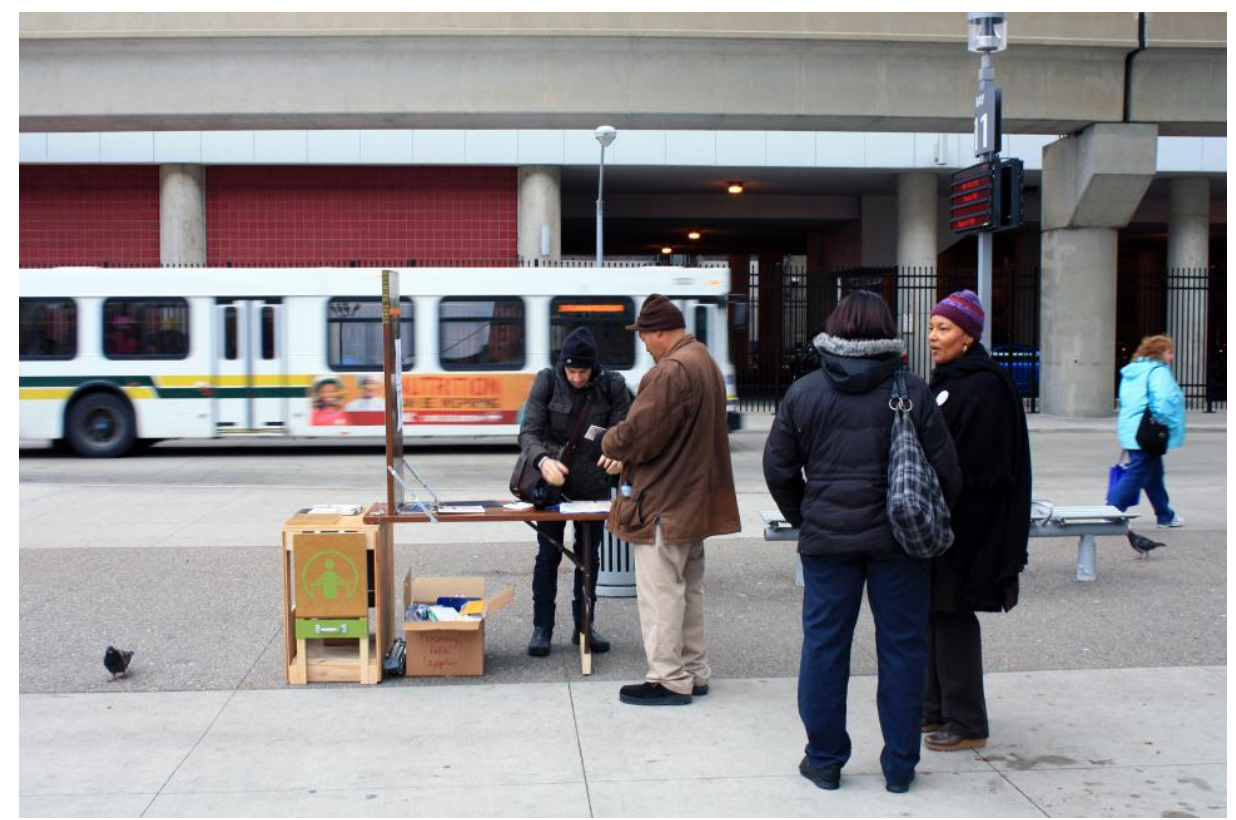

A third tactic that attracted a good diversity of participants, particularly youth, was an online planning game called Detroit 24/7 [34]. The game was intended to gather input about elements of the strategic framework using a fun and interactive game platform. The idea to use game design was rooted in the theory that online social games can promote an environment for civic learning where engagement is combined with active participation and reflection [35]. More specifically, the tactic offered a new and innovative venue for trust building within and across the communities, as well as fostering recognition of alternative perspectives and ideas through reflection and discussion [35]. The platform for DWPLTP was designed as part of a Knight Foundation grant to Community PlanIt, a project of the Engagement Game Lab of Emerson College. The engagement and technical teams worked closely with Community PlanIt to determine the platform's content, approach, and language. The game featured challenges, a point system and leaderboard, prizes, and awards - all of which encouraged friendly competition and active game play. The game was open to people of all ages, but over the course of three weeks, DWPLTP partnered with Detroit Public Schools and youth 
organizations, setting up computer kiosks in schools and libraries to allow easy access to the game to ensure young people had a voice in the process (see Figure 6). Partner outreach was a key facet of this engagement tactic, as it allowed the project to achieve scale. Detroit 24/7 [36] succeeded in helping to engage young people in the planning process, with 8400 comments being submitted to inform the strategic framework. The game culminated in a face-to-face event, yet another opportunity to foster two-way conversation between participants and members of the project team.

Figure 6. A high percentage of young people between the ages of 10 to 24 participated in the project's online planning game "Detroit 24/7". (Photo credit: Detroit Collaborative Design Center).

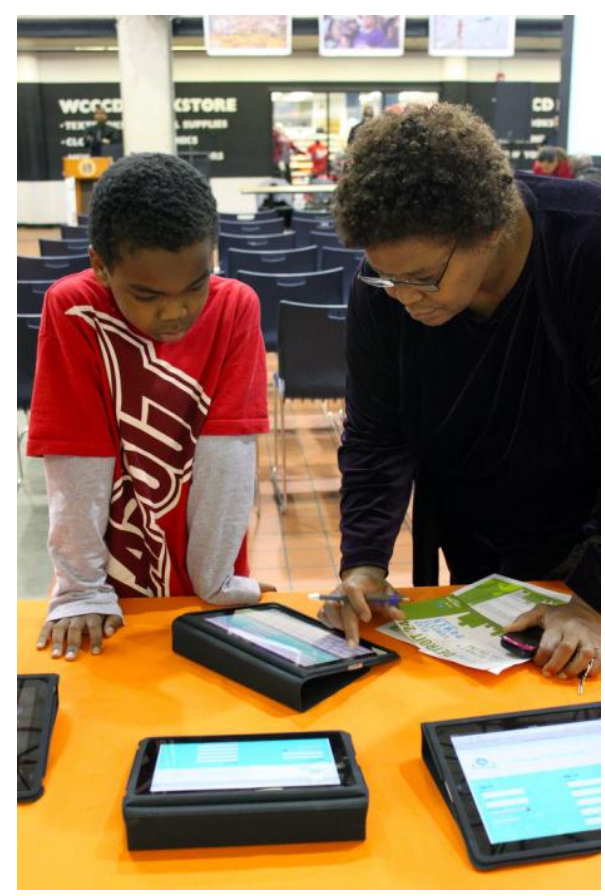

One participant, George, wrote "I think it's great when artists are able to harness their visions and engage community in meaningful ways." And this translated into several quality of life recommendations within the new neighborhood designs for the "live + make" neighborhoods featured in the strategic framework. Another game participant suggested, "Projects like the Riverwalk's wetlands filter clean the water and bring back animals." This suggestion and several like it influenced the team's approach to blue and green landscape infrastructure strategies, which can be found in the land use and city systems chapters of the Framework.

Lastly, an oral history project called Detroit Stories [36] aimed to solicit, video record, and share everyday stories of Detroiters. This tactic was an example of an effective way to increase awareness and enthusiasm about the project and celebrate people as one of Detroit's greatest assets. Through Detroit Stories, dozens of these video stories were gathered to learn about the personal perspectives of Detroiters and the things that mattered most in their lives. Since real Detroiters shared stories in their own words, the oral history project offered a highly engaging way to highlight conversation and stories and to inspire further reflections and input from participants following the video viewings. Watched by hundreds of people throughout the process, the Detroit Stories videos also provided an archive of rich, personal stories that could be preserved and shared even beyond the scope of the project. 
Each of these tactics was designed to enable ongoing, two-way conversations among participants and project team members. These methods successfully engaged a combination of different demographics, sectors, constituencies, and geographic areas throughout the city. Some of the tactics allowed for more in-depth conversation and input, while others allowed wider reach and raised broad awareness of the project. By contrast, other tactics were designed to inform more directly the technical aspects of the strategic framework. While the tactics varied in terms of the depth of input and feedback received, together they advanced the three objectives of building enthusiasm and trust, building engagement capacity, and fostering community learning and dialogue. In short, the engagement tactics enabled the planning conversation amongst Detroiters to extend beyond the start and end of a meeting.

However, executing such a diverse menu of ways to engage the community also required investing time, money, and attention to advance planning. Careful thought to logistics and event details was vital. On the front end, project leaders had to reimagine the purpose and structure of each meeting and how the series of meetings and events fit together. The deliberate planning also included identifying the target participants for a particular meeting as well as promotion and outreach to ensure robust attendance. Attention was given to designing the agenda and flow of a meeting, securing skilled and trusted facilitators, and identifying the format and key discussion questions. In addition, project organizers devoted significant time to important details such as optimal timing, venue, accessibility, childcare, language translation, creating a welcoming atmosphere, capturing ideas and input accurately, and other factors to maximize inclusivity and participation. These are considered some of the most effective and necessary practices for inclusive and participatory engagement [37]. Finally, organizers debriefed after the meetings and followed up to thank and update participants - a step commonly forgotten in event planning. All of these steps made project events and meetings more effective and successful.

\section{Conclusions}

The DWPLTP planning process culminated in January 2013, as Detroit Future City: 2012 Detroit Strategic Framework Plan was released to significant acclaim across sectors. After nearly three years of dialogue, analysis, planning, and collaborative work by a variety of community sectors, consultants, and civic leaders, this comprehensive strategic framework represented a shared vision for the future of the city's economic health, land use reform, neighborhood revitalization, public service delivery, management of abandoned lands, and elevation of civic capacity to implement and sustain change.

All in all, the scope and scale of civic participation in the Detroit Works Project: Long-Term Planning process was unprecedented in Detroit. The project conducted hundreds of meetings, had 30,000 conversations, connected with people over 163,000 times, and incorporated more than 70,000 surveyed responses and comments from participants [38]. Relationships, trust, buy-in, and momentum were invested in and built. The participation was inclusive in terms of race, age, gender, and neighborhood/geographic area, as shown in Figures 7-10. 
Figure 7. Map of all registered participants of DWPLTP within Detroit who provided race and ethnicity. (Image credit: Detroit Future City: 2012 Detroit Strategic Framework Plan).

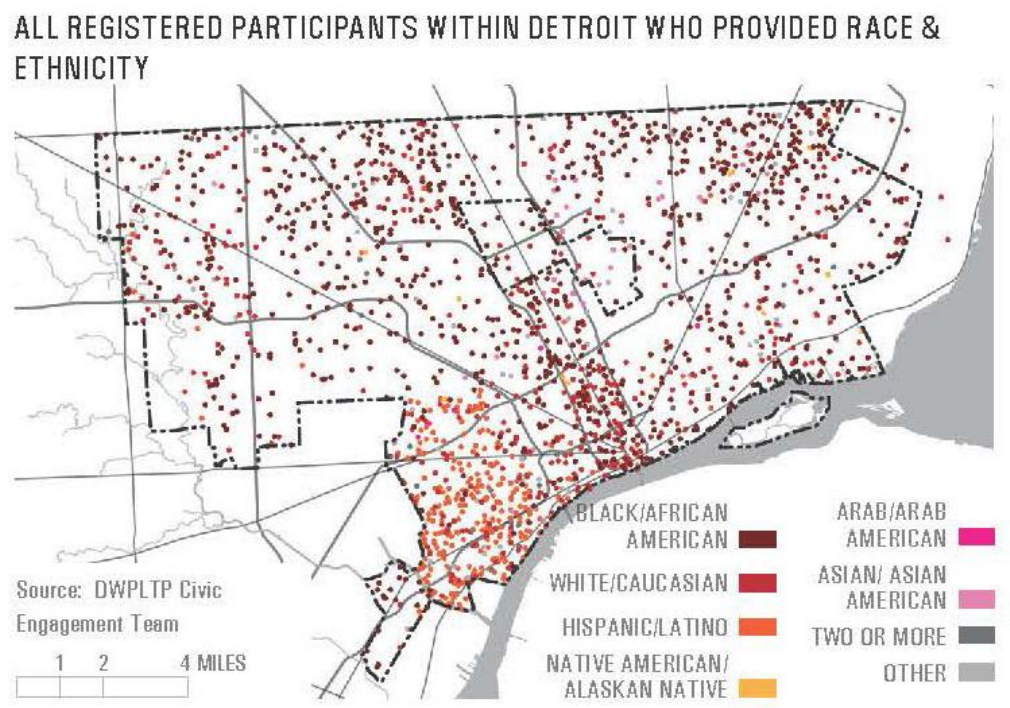

ALL REGISTERED PARTICIPANTS WHO PROVIDED RACE AND ETHNICITY, $46.8 \%$ BLACK/AFRICAN AMERICAN, $30.3 \%$ WHITE CAUCASIAN, $13.8 \%$ HISPANIC/LATINO, $3.8 \%$ OTHER, $2.1 \%$ ASIAN/ASIAN AMERICAN,

\section{RACE AND ETHNICITY}

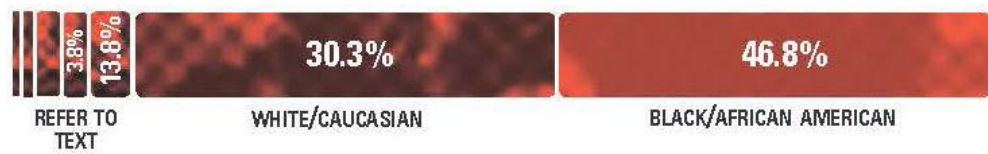

Figure 8. Map of all registered participants of DWPLTP within Detroit who provided gender. (Image credit: Detroit Future City: 2012 Detroit Strategic Framework Plan).

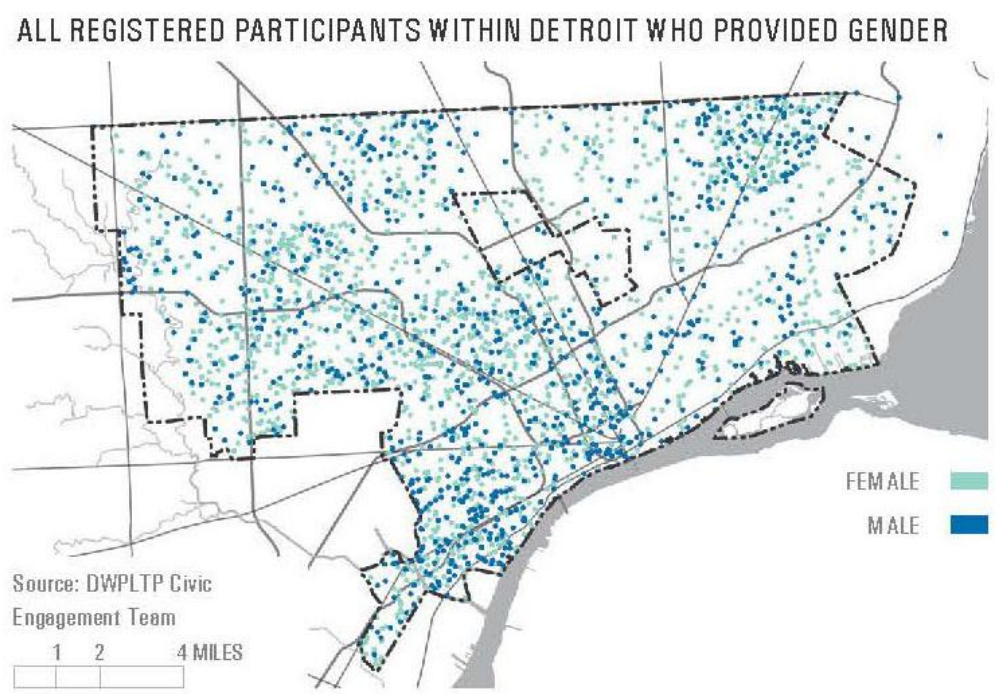

ALL REGISTERED PARTICIPANTS WHO PROYIDED GENDER, $61.5 \%$ FEMALE AND $38.5 \%$ MALE.

\section{GENDER}

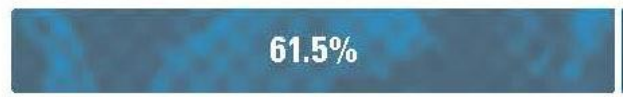

FEMALE
$38.5 \%$ 
Figure 9. Map of all registered participants of DWPLTP within Detroit who provided age. (Image credit: Detroit Future City: 2012 Detroit Strategic Framework Plan).

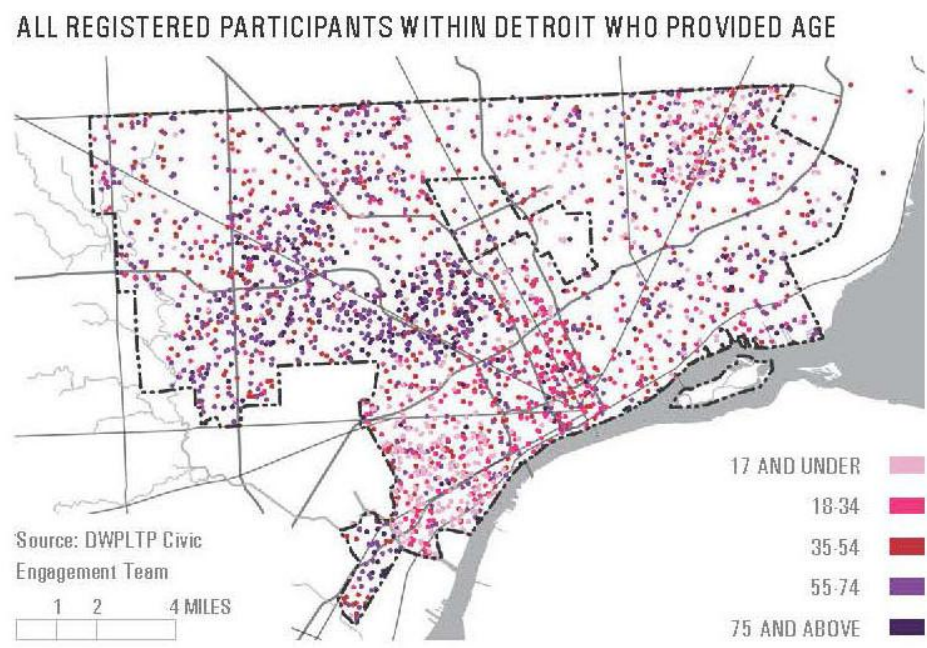

ALL REGISTERED PARTICIPANTS WHO PROVIDED AGE, 14.1\% 17 YEARS AND UNDER, 21.3\% EIGHTEEN YEARS AND UNDER, $22.8 \% 35-54$ YEARS, $31.9 \% 55-74$ YEARS, $9.9 \% 75$ YEARS AND OLDER.

AGE

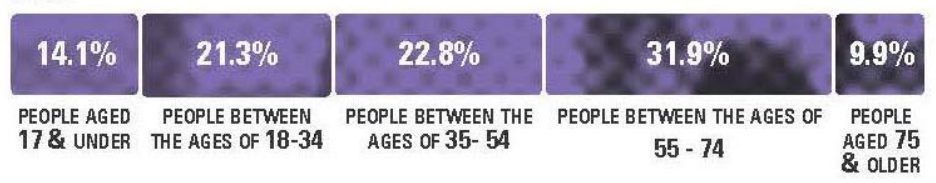

Figure 10. Map of all registered participants of DWPLTP within Detroit who provided geography. (Image credit: Detroit Future City: 2012 Detroit Strategic Framework Plan).

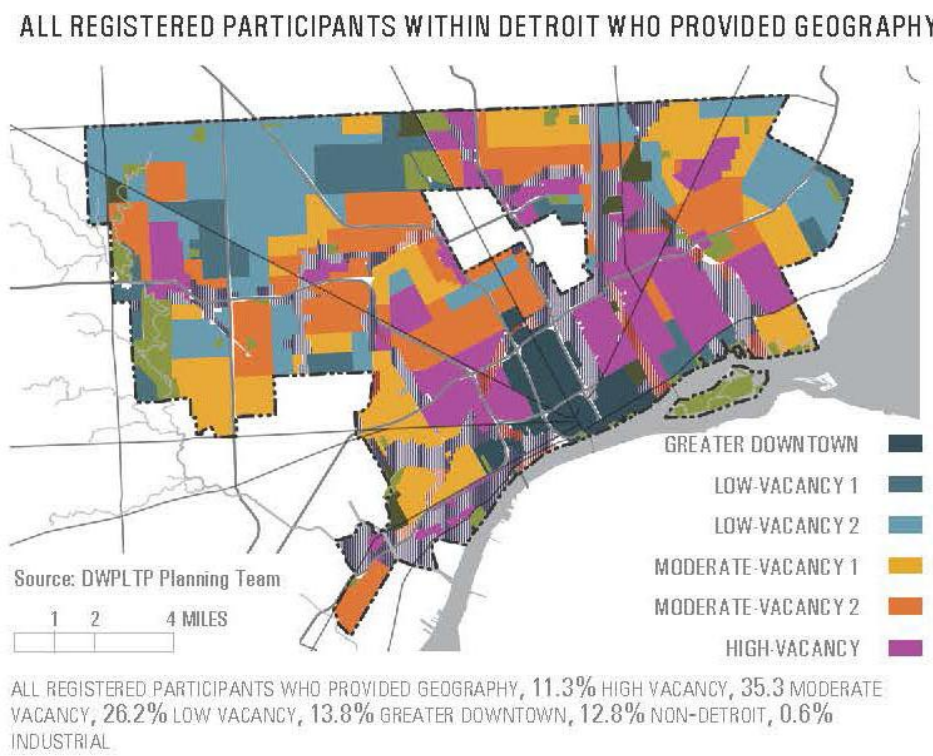

\section{GEOGRAPHY}

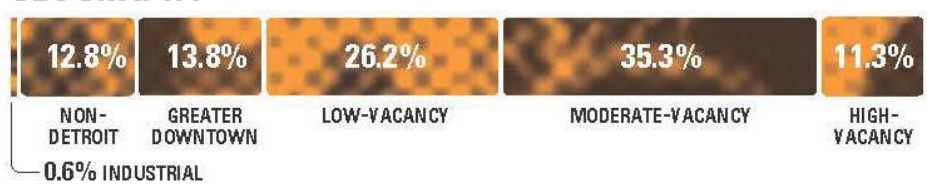

Perhaps most notably, most of the Process Leaders who were involved deeply in the civic engagement process have continued meeting regularly on a voluntary basis, sharing learning, 
collaborating, and continuing to champion the strategic framework within their own networks. Each Process Leader helps raise the visibility of different aspects of the strategic framework. For instance, one member of the group highlights the need to "repurpose land to provide one of our most basic needs - healthy food" [39], while others champion aspects such as community development, blight removal, the activation of block clubs, and small business incubation. These community leaders continue to shine a light on the need for civic engagement as Detroit Future City begins to be implemented across the city, and they raise both critiques and ideas in order for the project to remain accountable to all segments of community.

The success of the strategic framework plan can be measured in at least four distinct ways. First, the extraordinary amount of multi-sector involvement in the planning process was unprecedented. Over 200 local business, nonprofit, faith-based, institutional and grassroots organizations, together with governmental working groups, a Mayor's Advisory Task Force participated actively in the creation of the Framework. Second, government, private, nonprofit and philanthropic organizations have adopted all or parts of the Framework into their strategic investment plans for Detroit. Third, the strategic framework and the civic engagement process received over one million largely positive media impressions within the first month of its release and three professional recognitions including the American Planning Association's Daniel Burnham Award for a Comprehensive Plan, the Michigan Association of Planning's Planning Excellence Award, and the Michigan Chapter of the American Society of Landscape Architects' Honor Award for Landscape Planning and Analysis. The Detroit Collaborative Design Center was also given a SEED Award for Excellence in Community Interest Design in 2014, by Design Corps and the Social Economic Environmental Design ${ }^{\circledR}$ (SEED) Network, for several of its engagement approaches and materials.

The fourth, and perhaps most important, measurement of success is the ongoing commitment of Detroiters and the enhanced civic capacity across sectors to implement change through collaboration, partnerships and strategic coordination. Because the civic engagement process was designed around four key principles-overcoming cultural and racial dynamics, elevating local knowledge, blending community and technical expertise, and providing a wide range of opportunities to engage in two-way conversation - the strategic framework was solidified as the definitive way forward for reinventing the city's future [40]. The investment in building trust, fostering community learning, and strengthening local engagement capacity paid off in the end, as community members were able to see themselves reflected in the resulting strategic framework. Though the process was far from perfect, the willingness of project leaders to be responsive and make adjustments along the way was critical to the largely successful outcome.

To be sure, significant concern remains about whether this enhanced community capacity will continue to be meaningfully included in the process of implementation. The composition of newly elected and first-time city government officials and the uncertainty of the emergency manager and bankruptcy resolution at the time this article was completed leave many unsure about how well local government will partner with all community sectors going forward. In fact, the media often criticizes Detroit Future City for not being able to confirm the roles of community members in implementation, citing "we engage our citizens for feedback but leave them on the sidelines when it comes time for deployment" [41]. 
Some of the enduring capacity that was developed through the process included exposure to new engagement tools and tactics, the expansion of local leadership capability, and an increased ability to communicate and collaborate across siloes. Examples of this sustained capacity include the creation and funding of the Detroit Future City Project Implementation Office, which is staffed by a diverse group of multi-generational Detroit leaders; the participation of several young planning activists who ran for city council seats in the 2013 elections, all of whom were new to politics; and the incorporation of Detroit Future City's goals and strategies into the implementation agendas of several public and philanthropic sector organizations, including the Kresge Foundation and the Detroit Economic Growth Corporation. Over the last eighteen months since the plan's release, Detroit Future City has become a relevant framework for guiding collaboration, investment, and action, as Detroiters across all community sectors, including new government leadership at the state and local levels, continue to access, learn about, and integrate the framework into their efforts on the ground.

\section{Acknowledgments}

The authors would like to acknowledge the hard work of all who were instrumental in the success of Detroit Works Project: Long-Term Planning, particularly the members of the Steering Committee, the Office of the Mayor of Detroit, the City Council, the planning team, civic engagement and communications team, the Process Leaders, the Mayor's Advisory Task Force, partner organizations, and the various working groups and peer review group that lent their time and expertise to the process. We also extend special thanks to the project's funders and their staff: the Kresge Foundation, Ford Foundation, W.K. Kellogg Foundation, John S. and James L. Knight Foundation, Hudson Webber Foundation, Erb Family Foundation, and the Community Foundation for Southeast Michigan.

\section{Authors Contribution}

Planning Team: Toni L. Griffin, Hamilton Anderson Associates, Stoss Landscape Urbanism, Initiative for a Competitive Inner City, Mass Economics, Interface Studio, Happold Consulting, Center for Community Progress, and Carlisle Wortman. Civic Engagement Team: Detroit Collaborative Design Center, Michigan Community Resources, and Grassroots Solutions.

\section{Conflicts of Interest}

The authors declare no conflict of interest.

\section{References}

1. Leighninger, M. Creating Spaces for Change: Working Towards a "Story of Now" in Civic Engagement; Deliberative Democracy Consortium and W.K. Kellogg Foundation: Battle Creek, MI, USA, 2010.

2. Pastor, M.; Ito, J.; Rosner, R. Transactions, Transformations, Translations: Metrics That Matter for Building, Scaling, and Funding Social Movements; USC Program for Environmental and Regional Equity (PERE): Los Angeles, CA, USA, 2011. 
3. Powell, J.R.J.; Hardaway, P. Recommendations for Assuring Robust Civic Engagement \& Equity in Detroit's Shrinking City Planning Effort; Metropolitan Organizing Strategy Enabling Strength (MOSES) and The Kirwan Institute for the Study of Race and Ethnicity; Ohio State University: Columbus, OH, USA, 2010.

4. Barnes, W.; Mann, B. Making Local Democracy Work: Municipal Officials' Views about Public Engagement; Center for Research and Innovation, National League of Cities: Washington, DC, USA, 2010; pp. 13-18.

5. Detroit Works Project: Long-Term Planning. Civic Engagement Appendix: Supporting Lasting Civic Capacity in Detroit; Detroit Economic Growth Corporation: Detroit, MI, USA, January 2013. Available online: http://detroitworksproject.com/wp-content/uploads/2013/01/05-CivicEngagement.pdf (accessed on 31 January 2014).

6. Cramer, C. Detroit Engagement Audit Report; Grassroots Solutions: Minneapolis, MN, USA, 2010.

7. WCHB News Detroit. Mayor Dave Bing Gives State of the City Address. 24 March 2010. Available online: http://wchbnewsdetroit.newsone.com/246091/mayor-dave-bing-gives-state-ofthe-city-address-full-text/ (accessed on 19 August 2014).

8. Hoene, C.; Kingsley, C.; Leighninger, M. Bright Spots in Community Engagement: Case Studies of U.S. Communities Creating Greater Civic Participation from the Bottom Up; National League of Cities: Washington, DC, USA, 2013; pp. 8-9.

9. Detroit Future City: 2012 Detroit Strategic Framework Plan; Project of Detroit Future City (DFC) Strategic Framework; DFC Implementation Office: Detroit, MI, USA, December 2012. Available online: http://detroitworksproject.com/wp-content/uploads/2013/01/The-DFC-Plan.pdf (accessed on 7 October 2013).

10. Clark, A. Dave Bing's Detroit. The American Prospect, 2 October 2013. Available online: http://prospect.org/article/dave-bing\%E2\%80\%99s-detroit (accessed on 21 April 2014).

11. Davey, M. The Odd Challenge for Detroit's Planners. New York Times, 5 April 2011. Available online: http://www.nytimes.com/2011/04/06/us/06detroit.html?pagewanted=1\&_r= $2 \& \mathrm{sq}=\mathrm{detroit} \& \mathrm{st}=\mathrm{cse} \& \mathrm{scp}=1$ (accessed on 21 April 2014).

12. Cramer, C. Detroit Engagement Audit Report; Grassroots Solutions: Minneapolis, MN, USA, 2010; p. 30.

13. Cramer, C. Detroit Engagement Audit Report; Grassroots Solutions: Minneapolis, MN, USA, 2010; p. 51.

14. Chavez, C.; Matsumura, E.; Bacon, D. Mo(vement) Town: Building Civic Engagement in the Detroit Region; Working Partnerships USA; Detroit Collaborative Design Center; the Ford Foundation: San Jose, CA, USA, 2011; pp. 6-10.

15. Oakley, D.; Tsao, H. A new way of revitalizing distressed urban communities? assessing the impact of the federal empowerment zone program. J. Urban Aff. 2006, 28, 443-471.

16. Cramer, C. Detroit Engagement Audit Report; Grassroots Solutions: Minneapolis, MN, USA, 2010; pp. $13-15$.

17. State and County Quick Facts; U.S. Department of Commerce, United States Census Bureau: Allegany, NY, USA. Available online: http:/quickfacts.census.gov/qfd/states/26/2622000.html (accessed on 7 January 2014). 
18. Cramer, C. Detroit Engagement Audit Report; Grassroots Solutions: Minneapolis, MN, USA, 2010; pp. 26-28.

19. Ishem, L.H. Beyond Insiders and Outsides: Conceptualizing Multiple Dimensions of Community Development Stakeholders. In The Paradox of Urban Space; Sutton, S.E., Kemp, S.P., Eds.; Palgrave Macmillan: Hampshire, UK, 2011; p. 95.

20. Manzo, L.C.; Perkins, D.D. Finding common ground: The importance of place attachment to community participation and planning. J. Plan. Lit. 2006, 20, 340.

21. Detroit Works Project: Long-Term Planning Project Website. Available online: http://www.detroitworksproject.com (accessed on 31 January 2014).

22. Detroit Works Project: Long-Term Planning. In Civic Engagement Appendix: Supporting Lasting Civic Capacity in Detroit; Detroit Economic Growth Corporation: Detroit, MI, USA, January 2013; p. 91. Available online: http://detroitworksproject.com/wp-content/uploads/2013/01/05Civic-Engagement.pdf (accessed on 31 January 2014).

23. City versus Suburb: A Longstanding Divide in Detroit. Weekend Edition Sunday, National Public Radio, 9 March 2014. Available online: http://www.npr.org/2014/03/09/287877060/city-versussuburb-a-longstanding-divide-in-detroit (accessed on 21 April 2014).

24. ARISE Detroit! Unites Groups across the City. The Kresge Foundation, 4 February 2014. Available online: http://kresge.org/news/news-extra/arise-detroit-unites-groups-acrosscity\#sthash. 28AyDIQ6.dpuf (accessed on 22 April 2014).

25. Kemp, S.P.; Sutton, S.E. Integrating social science and design inquiry through interdisciplinary design charettes: An approach to participatory community problem solving. Am. J. Commun. Psychol. 2006, 38, 125-139.

26. Detroit Works Project: Long-Term Planning. In Civic Engagement Appendix: Supporting Lasting Civic Capacity in Detroit; Detroit Economic Growth Corporation: Detroit, MI, USA, January 2013; p. 227. Available online: http://detroitworksproject.com/wp-content/uploads/2013/01/05Civic-Engagement.pdf (accessed on 31 January 2014).

27. Mugerauer, R.; Manzo, L. Environmental Dilemmas: Ethical Decision Making (Toposophia: Sustainability, Dwelling, Design); Lexington Books: Lanham, Maryland, USA,, 2008; pp. 24-27.

28. Detroit Works Project: Long-Term Planning. In Civic Engagement Appendix: Supporting Lasting Civic Capacity in Detroit; Detroit Economic Growth Corporation: Detroit, MI, USA, January 2013; p. 49. Available online: http://detroitworksproject.com/wp-content/uploads/2013/01/05Civic-Engagement.pdf (accessed on 31 January 2014).

29. Detroit Works Project: Long-Term Planning. In Civic Engagement Appendix: Supporting Lasting Civic Capacity in Detroit; Detroit Economic Growth Corporation: Detroit, MI, USA, January 2013; p. 175. Available online: http://detroitworksproject.com/wp-content/uploads/2013/01/05Civic-Engagement.pdf (accessed on 31 January 2014).

30. Detroit Works Project: Long-Term Planning. In Civic Engagement Appendix: Supporting Lasting Civic Capacity in Detroit; Detroit Economic Growth Corporation: Detroit, MI, USA, January 2013; p. 145. Available online: http://detroitworksproject.com/wp-content/uploads/2013/01/05Civic-Engagement.pdf (accessed on 31 January 2014). 
31. Lukensmeyer, C.; Goldman, J.; Brigham, S. A Town Meeting for the Twenty-First Century. In The Deliberative Democracy Handbook: Strategies for Effective Engagement in the 21st Century, 1st ed.; Gastil, J., Levine, P., Eds.; Jossey-Bass: San Francisco, CA, USA, 2005; pp. 154-163.

32. Detroit Works Project: Long-Term Planning. In Civic Engagement Appendix: Supporting Lasting Civic Capacity in Detroit; Detroit Economic Growth Corporation: Detroit, MI, USA, January 2013; p. 158. Available online: http://detroitworksproject.com/wp-content/uploads/2013/01/05Civic-Engagement.pdf (accessed on 31 January 2014).

33. Detroit Works Project: Long-Term Planning. In Civic Engagement Appendix: Supporting Lasting Civic Capacity in Detroit; Detroit Economic Growth Corporation: Detroit, MI, USA, January 2013; p. 160. Available online: http://detroitworksproject.com/wp-content/uploads/2013/01/05Civic-Engagement.pdf (accessed on 31 January 2014).

34. Detroit 24/7 Online Game; Community PlanIt. Available online: http://detroitworksproject.com/ engagement/detroit247 (accessed on 31 January 2014).

35. Gordon, E.; Baldwin-Philippi, J. Playful civic learning: Enabling reflection and lateral trust in game-based public participation. Int. J. Commun. 2014, 8, 759-786.

36. Detroit Stories Oral History Project Website. Available online: http://www.detroitstoriesproject.com (accessed on 31 January 2014).

37. Creighton, J.L. The Public Participation Handbook: Making Better Decisions Through Citizen Involvement; Wiley: Jossey-Bass: San Francisco, CA, USA, 2005; pp. 85-179.

38. Detroit Works Project: Long-Term Planning. In Civic Engagement Appendix: Supporting Lasting Civic Capacity in Detroit; Detroit Economic Growth Corporation: Detroit, MI, USA, January 2013; pp. 322-333. Available online: http://detroitworksproject.com/wp-content/uploads/ 2013/01/05-Civic-Engagement.pdf (accessed on 31 January 2014).

39. Turner-Handy, S. A Common Theme throughout the Detroit Future City Framework. Michigan Citizen, 28 March 2013. Available online: http://michigancitizen.com/urban-agriculture-as-a-toolto-help-revitalize-the-city/ (accessed on 22 April 2014).

40. Thompson, A.; Wheeler, H. Commentary: No Debate, Detroit Future City Is the People's Plan. MLive, 3 April 2014. Available online: http://blog.mlive.com/news/detroit_impact/print.html? entry=/2014/04/commentary_no_debate_detroit_f.html. (accessed on 21 April 2014).

41. Lorimer, J. Detroit Future City Is Full of Small Mistakes. HuffPost Detroit, 22 January 2013. Available online: http://www.huffingtonpost.com/jason-lorimer/full-of-small-mistakes_b_ 2517018.html (accessed on 5 May 2014).

(C) 2014 by the authors; licensee MDPI, Basel, Switzerland. This article is an open access article distributed under the terms and conditions of the Creative Commons Attribution license (http://creativecommons.org/licenses/by/4.0/). 